\title{
Effects of predation by the scyphomedusan Chrysaora quinquecirrha on zooplankton populations in Chesapeake Bay, USA
}

\author{
Jennifer E. Purcell \\ Horn Point Environmental Laboratory, PO Box 775, Cambridge, Maryland 21613, USA
}

\begin{abstract}
The diet, digestion times, and densities of Chrysaora quinquecirrha medusae, and densities of their prey were quantified in order to evaluate the importance of this conspicuous scyphomedusan on zooplankton populations in Chesapeake Bay, USA, and its tributaries. Medusae consumed a variety of zooplankton prey, but copepods, mostly Acartia tonsa, averaged $55 \%$ of the prey items in gut contents collected during July and August from 2 tributaries of Chesapeake Bay in 1987 and 1988, and $71 \%$ of the prey in gut contents from the main bay in 1987-1990. Medusae showed positive selection for copepods, but negative selection for copepod nauplii. Digestion times of copepods by medusae averaged $3.5 \mathrm{~h}$. A multiple regression equation related digestion times to temperature and the number of ingested copepods, but not to medusa size. Predation rates (numbers of copepods consurned medusa $a^{-1} \mathrm{~d}^{-1}$ ) increased with increasing prey density, medusa diameter, and temperature. These results provide a means of predicting C. quinquecirrha feeding in situ. Greater numbers of prey in medusae at nighttime than during the day probably were due to greater prey densities at night. Daily predation effects (percentage of the copepod standing stock consumed $d^{-1}$ ) were calculated from feeding rates, and the densities of medusae and copepods. Medusa densities (peaks of 11 to $16 \mathrm{~m}^{-3}$ ) and predation effects (peaks of 42 to $94 \% \mathrm{~d}^{-1}$ of the copepods consumed) were much greater in the 2 tributaries than at a nearshore station in the bay (peaks of 2 medusae $\mathrm{m}^{-3}$ and $3 \% \mathrm{~d}^{-1}$ of the copepods consumed). Ingestion of zooplankton provided an average of $145 \%$ of the nitrogen needed to balance excretion in medusae $<45 \mathrm{~mm}$ in diameter, but supplied only $65 \%$ of the nitrogen needs of medusae $>45 \mathrm{~mm}$. Other prey, including ctenophores, fish eggs and larvae, and large polychaete worms are additional contributions to the diet. Predation by $C$. quinquecirrha medusae may control copepod populations in some tributaries of Chesapeake Bay, as suggested by high predation effects and declining copepod populations throughout the summer.
\end{abstract}

\section{INTRODUCTION}

Scyphomedusae are large, conspicuous predators in coastal zooplankton communities, yet few quantitative studies document their effects on prey populations. Predation on fish eggs and larvae and on copepods has been estimated as 2 to $5 \%$ of the standing stocks consumed $d^{-1}$ (Moller 1980, Fancett \& Jenkins 1988). In other studies, feeding or clearance rates of scyphomedusae have been measured, but the studies lacked necessary data to calculate predation rates on prey populations (Feigenbaum et al. 1982, Kelly 1983, Morand et al. 1987, Bamstedt 1990, Larson 1991).

Chrysaora quinquecirrha medusae, known locally as sea nettles, occur in such great abundance during the summer in the mesohaline region of Chesapeake Bay, USA, that methods were evaluated for control of their populations during 1968 to 1972 (Schultz \& Cargo 1971, Haven \& Morales-Almo 1973). Young C. quinquecirrha medusae (ephyrae $1 \mathrm{~mm}$ in diameter) are produced in shallow water by benthic polyps (scyphistomae) in early spring (Cargo \& Schultz 1966, 1967). Medusa population abundances have been linked to environmental factors, particularly stream flow, salinity, and temperature (Cargo \& King 1990).

Observed changes in the plankton community (Feigenbaum \& Kelly 1984), and a model of Chesapeake Bay food webs (Baird \& Ulanowicz 1989) suggest that Chrysaora quinquecirrha medusae are extremely important in the plankton dynamics of the 
bay; however, the feeding rates of the medusae were not measured in these studies. Clearance rates of the medusae, measured in the laboratory with Artemia salina nauplii as prey, increased with increasing prey density (Clifford \& Cargo 1978. Feigenbaum et al. 1982). Feeding rates, determined by analysis of gut contents and digestion rates, increased with medusa size (Kelly 1983)

In the present study, I sampled in 2 tribuaries in the mesohaline region of Chesapeake Bay, and also in the main bay. I quantified the diet and prey selection of Chrysaora quinquecirrha medusae, calculated feeding rates on copepods (copepodites and adults) from gut contents and digestion rates, and developed a predictive equation to estimate feeding rates from field data on prey density, medusa diameter, and water temperature. Based on the percentages of copepod standing stocks consumed daily by C. quinquecirrha medusae, I conclude that medusae may have controlled copepod populations during the summer in the 2 tributaries, but not in Chesapeake Bay.

\section{MATERIALS AND METHODS}

Sampling dates and locations. Two tributaries of the Choptank River - Broad Creek $\left(38^{\circ} 40^{\prime} \mathrm{N}, 76^{\circ} 15^{\prime} \mathrm{W}\right)$ and the Tred Avon River $\left(38^{\circ} 40^{\prime} \mathrm{N}, 76^{\circ} 05^{\prime} \mathrm{W}\right)$ were sampled weekly from June through September 1987, and monthly in 1988. The site within each tributary was $\leq 3 \mathrm{~m}$ deep. The 2 sampling sites were near oyster bars as part of another study. The sampling was not designed to examine spatial heterogeneity along the axis of the tributary. Instead, I compare the tributary sites with a nearby station (Stn 5) in Chesapeake Bay.

Sampling was conducted on 13 dates during July through September 1987 to 1990 at 5 stations on a transect across Chesapeake Bay $\left(38^{\circ} 33^{\prime} \mathrm{N}, 76^{\circ} 22^{\prime}\right.$ to $\left.76^{\circ} 30^{\prime} \mathrm{W}\right)$. Sampling began at the easternmost station (Stn 5) near the mouth of the Choptank River at ca 06:30 h and was completed at Stn 1 by $12: 00 \mathrm{~h}$ or 13:00 h. In order to determine diel patterns in Chrysaora quinquecirrha medusa feeding, sampling also occurred during the day and at midnight at Stn 4 in the main channel on 1 date each in 1987 and 1990. Temperature, salinity, and dissolved oxygen were measured throughout the water column with a Combined Temperature and Depth probe. Biological sampling was restricted to above the pycnocline $(11 \mathrm{~m})$, because deeper waters were deficient in dissolved oxygen (as in Malone et al. 1986).

Zooplankton densities. Zooplankton other than medusae was collected by a diaphram pump with a $2.5 \mathrm{~cm}$ diameter hose by pumping $20 \mathrm{I}$ water at $1 \mathrm{~m}$ depth in the tributaries, and at $1 \mathrm{~m}$ intervals above the pycnocline $(11 \mathrm{~m})$ at Stns $2,3 \& 4$, and above the bottom $(5 \mathrm{~m})$ at Stns $1 \& 5$ in the bay. The water was filtered through a $64 \mu \mathrm{m}$ mesh plankton net, and the samples preserved in $5 \%$ formalin. Densities were determined by counting all zooplankton from three $5 \mathrm{ml}$ subsamples taken with a Hensen stempel pipette. Crustacean zooplankters were identified to order, and other taxa to phylum.

Medusa biomass, densities, and size distributions. Medusae were collected in a $1 \mathrm{~m}$ diameter, $1.6 \mathrm{~mm}$ mesh plankton net with flowmeter in double-oblique tows to $1 \mathrm{~m}$ depth in the tributaries in 1987 and 1988 , and to $4 \mathrm{~m}$ depth at Stn 5 in Chesapeake Bay. The volumes of water filtered by the net averaged $46.8 \pm$ $19.5 \mathrm{~m}^{3}$ in the tributaries and $74.6 \pm 36.9 \mathrm{~m}^{3}$ at $\operatorname{Stn} 5$. Only data from Stn 5 are used here for comparision with the tributary sites in 1987, when sampling dates corresponded. These samples were drained in a colander, and the water filtered again through a $200 \mu \mathrm{m}$ mesh sieve to retrieve small specimens. Total live volume of medusae in each sample was measured in a $250 \mathrm{ml}$ or a $1 \mathrm{l}$ graduated cylinder. These samples then were preserved in $5 \%$ formalin, and specimens counted and their diameters measured in the laboratory.

Diet and prey selection. At the 5 bay stations and in both tributaries, Chrysara quinquecirrha medusae were collected individually by dip net and immediately preserved in $5 \%$ formalin. Diameters of the preserved medusae were measured to the nearest $1 \mathrm{~mm}$, and prey in the guts were identified with a dissecting microscope. Electivity indices $(C)$ for the common zooplankton taxa were calculated from the numbers of prey $\mathrm{m}^{-3}$ and the average numbers of prey medusae $e^{-1}$ for each sample, and the significance tested (chisquare) according to Pearre (1982).

Digestion rates. In order to measure the digestion times of Chrysaora quinquecirrha feeding on Acartia tonsa copepods (copepodites and adults), medusae were collected in jars from the boat basin of the Horn Point Environmental Laboratory (HPEL) on the Choptank River They were maintained in 201 containers for $24 \mathrm{~h}$ at ambient water temperature $(20$ to $27^{\circ} \mathrm{C}$ ) in $30 \mu \mathrm{m}$ filtered estuary water (11 to $12 \%$ salinity) with Artemia salina nauplii as prey, so that their guts would empty of copepod prey. A. tonsa copepods were collected with a $200 \mu \mathrm{m}$ mesh plankton net from the estuary and added to the containers with medusae. After a $0.5 \mathrm{~h}$ feeding period, each medusa was transferred gently to a 4 or 201 container with $30 \mu \mathrm{m}$ filtered water at the same temperature with $A$. salina nauplii supplied as food to promote natural gut emptying as digestion proceeded. Each medusa subsequently was transferred at $1 \mathrm{~h}$ intervals for 6 to $8 \mathrm{~h}$ to new containers of filtered water with $A$. salina. After 
the medusa was removed from each container, the water was poured through a $60 \mu \mathrm{m}$ screen and the copepod exoskeletons were counted with a dissecting microscope, thus recording all copepods egested each hour. The egestion time for each copepod was calculated from the midpoints of the feeding period and the digestion period when the exoskeleton appeared, so the accuracy is $\pm 0.75 \mathrm{~h}$. The egestion times for all copepods digested by each medusa were averaged to give a digestion time.

The relationship of digestion time to water temperature, numbers of prey in the guts, and medusa size was tested in a stepwise multiple regression. In situ digestion times for copepods were predicted from the regression equation, using the water temperature of the mixed layer and the number of copepods in the guts of medusae collected in the field.

Feeding rates and predation effects. Feeding rates of Chrysaora quinquecirrha on copepods were calculated for each medusa according to the following equation: $F=C_{\mathrm{m}} / D \times 24 \mathrm{~h} \mathrm{~d}^{-1}$, where $F=$ no. of copepods ingested medusa ${ }^{-1} \mathrm{~d}^{-1} ; C_{\mathrm{m}}=$ no. of copepods in the medusa; $D=$ digestion time (in h). The relationship of feeding rate to copepod density, medusa diameter, and water temperature was tested in a stepwise multiple regression.

For comparison with other studies, feeding rates $(F)$ were converted to clearance rates (liters cleared medusa ${ }^{-1} \mathrm{~d}^{-1}$ ) by dividing $F$ by the number of copepods $1^{-1}$. Feeding rates also were standardized to live medusa volume by first converting preserved diameter to live diameter and then to volume (Table 1), and finally dividing $F$ by medusa volume.

Predation effects on copepod populations were calculated by the following equation: $P=F \times M / C_{1} \times 100$, where $P=$ percentage of copepod standing stock consumed $\mathrm{d}^{-1} ; F=$ no. of copepods ingested medusa ${ }^{-1} \mathrm{~d}^{-1}$

Table 1 Biometric conversions used for Chrysaora quinquecirrha medusae. Previously unpublished results were from 59 medusae. Diam: live diameter ( $\mathrm{mm})$; vol: volume $(\mathrm{ml})$ WW: wet weight (mg); DW: dry weight (mg); C: carbon (mg) N: nitrogen (mg)

\begin{tabular}{|ll|}
\hline Diam & $=1.18$ preserved diameter $(\mathrm{mm})^{\mathrm{a}}$ \\
$\ln (\mathrm{vol})$ & $=2.45 \ln \left(\right.$ Diam) $-7.034^{\mathrm{b}}$ \\
$\mathrm{WW}$ & $=0.0486 \mathrm{Diam}^{3116}, \mathrm{r}=0.99$ \\
$\mathrm{DW}$ & $=0.0021 \mathrm{Diam}^{2.886}, \mathrm{r}=0.97$ \\
$\mathrm{C}$ & $=0.00215 \mathrm{Diam}^{2.903}, \mathrm{r}=0.96$ \\
$\mathrm{~N}$ & $=0.000271 \mathrm{Diam}^{2.509}, \mathrm{r}=0.90$ \\
$\mathrm{C}$ & $=0.105 \mathrm{DW}^{1.009}, \mathrm{r}=0.99$ \\
$\mathrm{~N}$ & $=0.022 \mathrm{DW}^{1.046}, \mathrm{r}=0.99$ \\
$\mathrm{C} / \mathrm{N}$ & $=3.9 \pm 0.1$ \\
& \\
d Nemazie (1991) \\
belly (1983)
\end{tabular}

$M=$ no. of medusae $\mathrm{m}^{-3} ;$ and $C_{1}=$ no. of copepods $\mathrm{m}^{-3}$ plus those in the medusae $\left(C_{m}\right)$. These data are presented in 1987 for the tributaries on dates that corresponded to sampling dates in the bay, for bay Stn 5 closest to the tributaries, and for monthly samples in the tributaries in 1988

In order to determine if the daily ingestion of copepods by Chrysaora quinquecirrha medusae was sufficient to balance their metabolic needs, I first calculated their live diameters and used these to calculate medusa body weights in dry weight and nitrogen based on conversion factors obtained from 59 medusae (Table 1). Ammonium excretion of $C$. quinquecirrha ( $\mu \mathrm{g}$ atoms $\mathrm{NH}_{4}{ }^{+}-\mathrm{N}$ medusa ${ }^{-1} \mathrm{~h}^{-1}$ ) was calculated according to the equation: $\log$ (excretion) $=0.134+$ 0.974 (log g dry wt) +0.021 (temp), which was determined for freshly-collected medusae (Nemazie 1991), and converted to $\mu \mathrm{g} \mathrm{NH}_{4}{ }^{+}-\mathrm{N}$ excreted medusa ${ }^{-1} \mathrm{~d}^{-1}$ by multiplying by $14 \mu \mathrm{g} \mathrm{NH}_{4}{ }^{+} \mathrm{N}$ ( $\mu$ g atoms $\left.\mathrm{NH}_{4}{ }^{+}\right)^{-1}$, and by $24 \mathrm{~h} \mathrm{~d}^{-1}$. This gave estimates of minimum ingestion necessary to balance excretion. Rations (zooplankters eaten medusa ${ }^{-1} \mathrm{~d}^{-1}$ ) were converted to $\mu \mathrm{g} \mathrm{N}$ assimilated medusa ${ }^{-1} \mathrm{~d}^{-1}$ by assuming the following nitrogen body weights ( $\mu \mathrm{g} N$ ) of Chesapeake Bay zooplankton: Acartia tonsa copepods $>200 \mu \mathrm{m}$ in cephalothorax length $=0.37$ and nauplii $=0.04 ;$ barnacle nauplii $=$ 0.36 ; rotifers $=0.16 ;$ mollusc veligers $=0.16$ (White 1991); and by assuming $90 \%$ assimilation efficiency (Purcell 1983)

All data are presented as means \pm 1 SD when 3 or more samples existed. $\mathrm{p}<0.05$ is considered statistically significant.

\section{RESULTS}

\section{Medusa biomass, densities, and size distributions}

For comparison with previous studies, I have reported Chrysaora quinquecirrha abundance as total live volume $\left(\mathrm{ml} \mathrm{m}^{-3}\right)$ (Fig. 1). In both Broad Creek and the Tred Avon River, medusa volume was greatest in July and August (peaks of 69 and $53 \mathrm{ml} \mathrm{m}^{-3}$ ), and generally decreased thereafter (Fig. 1). Medusa volume was low by September 25 in both tributaries. At bay Stn 5 , medusa volume peaked on August 6 at $22 \mathrm{ml} \mathrm{m}^{-3}$, but volumes on other dates were less than $5 \mathrm{ml} \mathrm{m}^{-3}$.

Medusa densities were always higher in the tributaries than at bay Stn 5 . On July 8 , the densities in Broad Creek and the Tred Avon River were 8.9 and $8.3 \mathrm{~m}^{-3}$, respectively, but were only 0.2 medusae $\mathrm{m}^{-3}$ on July 9 at Stn 5. Average densities in August were $6.3 \pm 3.1$ medusae $\mathrm{m}^{-3}$ in Broad Creek, and $8.0 \pm 4.2 \mathrm{~m}^{-3}$ in the Tred Avon River, but were only $1.6 \pm 0.7 \mathrm{~m}^{-3}$ at $\mathrm{Stn} 5$ The highest densities of medusae occurred in late July 


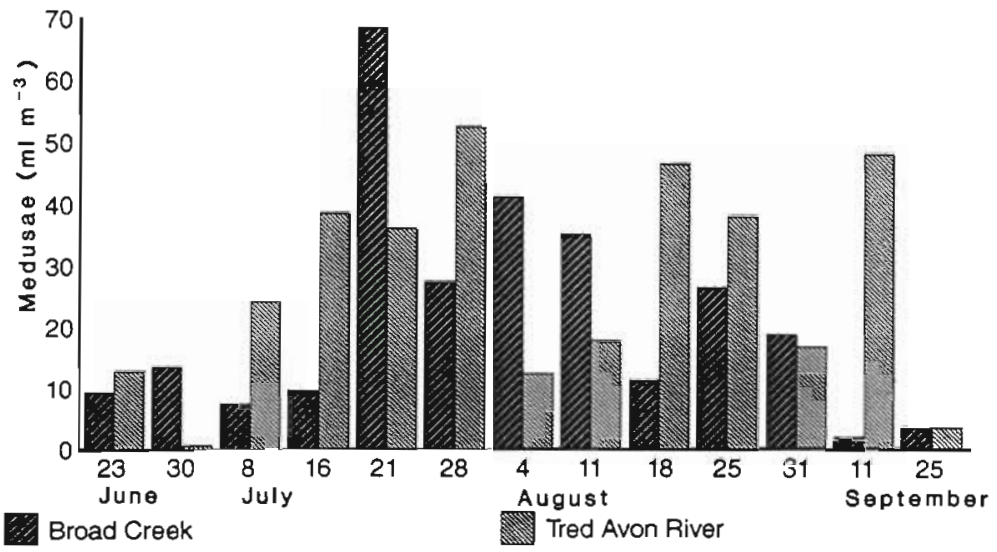

Fig. I Chrysaora quinquecirrha. Total live volumes of medusae collected in plankton samples from the Broad Creek and Tred Avon River tributaries of Chesapeake Bay during June through September 1987 to early August (as many as $18.6 \mathrm{~m}^{-3}$ ) in the tributaries, as illustrated for Broad Creek (Fig. 2). Medusa densities were $<1 \mathrm{~m}^{-3}$ in the tributaries in September.

Ephyrae and small medusae $(<26 \mathrm{~mm}$ in diameter) predominated in June 1987 in both tributaries. The size distributions of medusae over the summer in Broad Creek is shown as an example (Fig, 2). Medusae were smaller in the tributaries than at bay Stn 5. In July, 98.2 and $79.5 \%$ of the medusae in Broad Creek and the Tred Avon River were $<26 \mathrm{~mm}$ in diameter, but only $66.7 \%$ were $<26 \mathrm{~mm}$ at Stn 5. In August, $65.3 \%$ of the medusae were $<26 \mathrm{~mm}$ in both tributaries, but only $32.3 \%$ were $<26 \mathrm{~mm}$ at Stn 5 . Mostly medusae $>26, \mathrm{~mm}$ remained in the tributaries in September.

\section{Diet and prey selection}

Chrysaora quinquecirrha medusae consumed a wide variety of zooplankton prey. Copepods (copepodites and adults), primarily Acartia tonsa, were $54.6 \pm$ $21.8 \%$ of prey in 150 medusae from the tributaries in 1987 and 1988 , and $71.0 \pm 26.4 \%$ of the prey consumed by 240 medusae examined from the bay in 1987 to 1990 . On some dates, rotifers, cladocerans, or eggs of bay anchovy Anchoa mitchelli were extremely abundant in the water and in the diet. Data from 4 samples illustrate the effect on the diet when different proportions of prey were available in situ (Table 2). Medusae showed positive selection for copepods and negative selection for copepod nauplii $(\mathrm{p}<0.005$, Table 2). Selection for rotifers at $\operatorname{Stn} 5$ was negative on July 9, but was positive on August 6. Selection could be species specific, but rotifers were not identified to species. Bivalve larvae were selected against on 3 dates $(p<0.005)$. Selection for barnacle larvae and for cladocerans was not significantly different from zero.

\section{Digestion rates}

Digestion of copepods by Chrysaora quinquecirrha medusae averaged $3.5 \pm 1.1 \mathrm{~h}$. Digestion rates were strongly related to temperature (Fig. 3), were less strongly related to the number of prey in each medusa, and were not related to medusa size (Table 3). The multiple regression of temperature and prey number on digestion rate was more significant than either variable alone and explained $53 \%$ of the variation observed in digestion rates (Table 3 ).

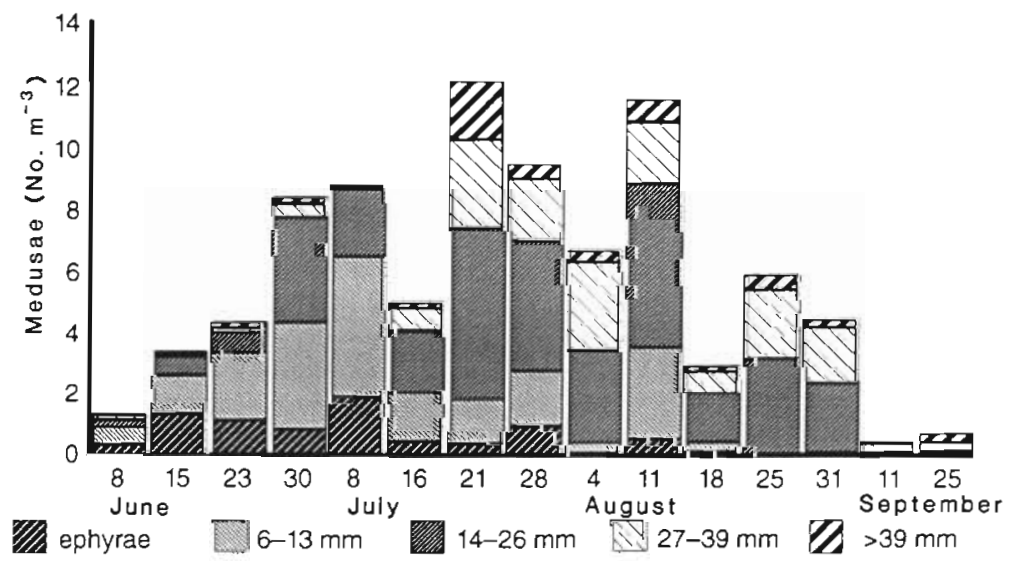

Fig. 2. Chrysaora quinquecirrha. Abundance and size distribution of ephyrae and medusae in the Broad Creek tributary of Chesapeake Bay during June through September 1987 
Table 2. Chrysaora quinquecirrha. Composition of zooplankton in the diet of medusae and in surface waters in 1987, and indices of prey selection $(C)$ according to Pearre (1982). No. of medusae examined for each sample are given in Table 5. ND: no data

\begin{tabular}{|c|c|c|c|c|c|c|c|}
\hline Date & Copepods & $\begin{array}{c}\text { Copepod } \\
\text { nauplii }\end{array}$ & $\begin{array}{c}\text { Barnacle } \\
\text { larvae }\end{array}$ & $\begin{array}{l}\text { Clado- } \\
\text { cerans }\end{array}$ & Rotifers & $\begin{array}{l}\text { Bivalve } \\
\text { larvae }\end{array}$ & Misc \\
\hline \multicolumn{8}{|c|}{ Tred Avon } \\
\hline No. prey medusa ${ }^{-1}$ & 49.7 & 0.4 & 1.1 & 0 & 0.8 & 2.3 & 5.6 \\
\hline No. prey $\mathrm{l}^{-1}$ & 6.5 & 45.1 & 1.5 & 0 & ND & 0.5 & ND \\
\hline$C$ & $0.776^{\circ}$ & $-0.826^{\circ}$ & -0.035 & - & - & 0.045 & - \\
\hline \multicolumn{8}{|l|}{ Aug 11} \\
\hline No. prey medusa ${ }^{-1}$ & 76.5 & 7.0 & 0.05 & 0 & 5.8 & 0.2 & 2.7 \\
\hline No. prey $]^{-1}$ & 18.2 & 79.7 & 0.2 & 0 & ND & 0.3 & ND \\
\hline$C$ & $0.716^{\circ}$ & $-0.716^{\circ}$ & -0.130 & - & - & $-0.098^{\circ}$ & - \\
\hline \multicolumn{8}{|c|}{ Bay Stn 5} \\
\hline No. prey medusa ${ }^{-1}$ & 3901.0 & 25.8 & 29.2 & 13.5 & 158.5 & 20.2 & 30.5 \\
\hline No. prey $1^{-1}$ & 46.2 & 194.1 & 1.6 & 0.4 & 28.7 & 16.2 & ND \\
\hline$C$ & $0.612^{\circ}$ & $-0.757^{\circ}$ & -0.001 & $<0.001$ & $-0.073^{\circ}$ & $-0.136^{\circ}$ & - \\
\hline \multicolumn{8}{|l|}{ Aug 6} \\
\hline No prey medusa ${ }^{-1}$ & 107.3 & 10.6 & 0 & 0.4 & 1160.8 & 2.4 & 8.0 \\
\hline No. prey $\mathrm{l}^{-1}$ & 23.2 & 360.9 & 0 & 0 & 293.8 & 54.2 & ND \\
\hline $\mathrm{C}$ & $0.100^{\circ}$ & $-0.602^{*}$ & - & - & $0.541^{\circ}$ & $-0.207^{\circ}$ & - \\
\hline$\cdot p<0.005$ & & & & & & & \\
\hline
\end{tabular}

\section{Feeding rates and predation effects}

Comparison of the numbers of prey in the gut contents of Chrysaora quinquecirrha medusae during the day and night on 2 dates in August $(1987,1990)$ in the mid Bay (Stn 4) showed that significantly more copepods were in the gut contents at night $(227 \pm 198$ medusa $^{-1}$ ) than in the day (98 \pm 80 medusa $^{-1}$; ANOVA, $p=0.02$ ). However, more copepods also occurred in surface waters at night $\left(54 \pm 1^{-1}\right)$ than in the day $\left(48 \pm 10 \mathrm{l}^{-1}\right.$; ANOVA, $\left.p=0.02\right)$. Diameters of the medusae did not differ significantly between night $(51 \pm 13 \mathrm{~mm})$ and day $(48 \pm 16 \mathrm{~mm}$; ANOVA, $\mathrm{p}=0.52)$

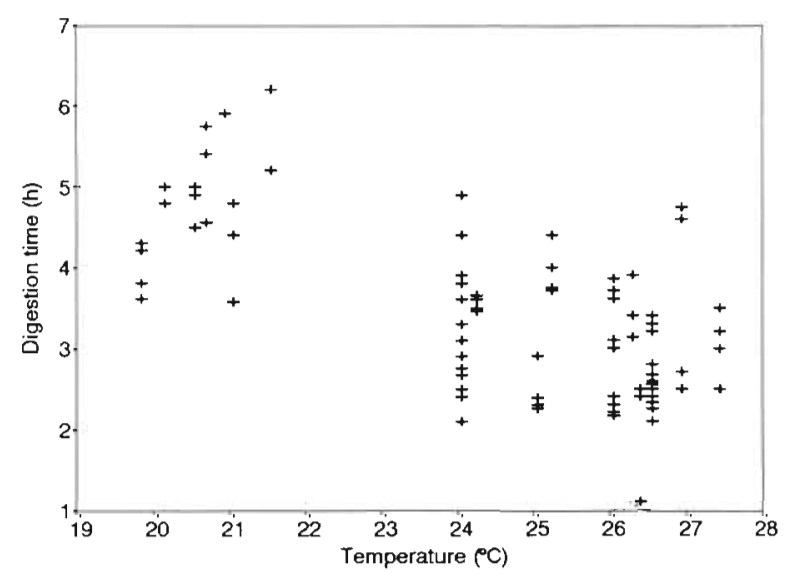

Fig. 3. Chrysaora quinquecirrha. Time required for medusae to digest copepods at various temperatures
Daytime and nighttime feeding relative to prey density could not be distinguished (Fig. 4). Therefore, more prey in the nighttime gut contents probably was due to the greater prey densities at night.

Feeding rates of Chrysaora quinquecirrha medusae ranged from 9.6 to 18682 copepods eaten medusa ${ }^{-1}$ $\mathrm{d}^{-1}$. These rates increased with increasing copepod density (Fig. 5A), medusa diameter (Fig. 5B), and temperature. Prey density was most strongly correlated with feeding rate of the 3 factors, which together explained $58 \%$ of the variation observed in feeding rate (Table 4 ). The multiple regression equation (Table 4) can be used to estimate in situ preda-

Table 3. Chrysaora quinquecirrha. Multiple regression analysis of water temperature, no. of copepod prey medusa ${ }^{-1}$, and live medusa diameter on digestion time of copepods by 89 medusae in laboratory experiments. Regression equation: $Y=10.86-0.31 X_{1}+0.001 X_{2}$; ANOVA $F=43.5, \mathrm{p}=$ $9.0 \times 10^{-14^{*}} ;$ SE of estimate $=0.76$

\begin{tabular}{|lcccc|}
\hline Variable & Range & Partial I $^{2}$ & $F$ & $\mathrm{p}$ \\
\hline $\begin{array}{l}X_{3}=\text { Tem- } \\
\text { perature }\left({ }^{\circ} \mathrm{C}\right)\end{array}$ & $20-27$ & 0.49 & 82.2 & $<0.0001^{\circ}$ \\
$\begin{array}{l}X_{2}=\text { Prey } \\
\text { medusa }\end{array}$ & $3-631$ & 0.04 & 3.14 & 0.08 \\
$\begin{array}{l}X_{3}=\text { Medusa } \\
\text { diameter (mm) } \\
Y=\text { Digestion }\end{array}$ & $25-126$ & 0.004 & 0.001 & 0.97 \\
$\begin{array}{l}\text { time (h) } \\
\text { Statistically significant }\end{array}$ & $1.1-6.2$ & - & - & - \\
\hline
\end{tabular}




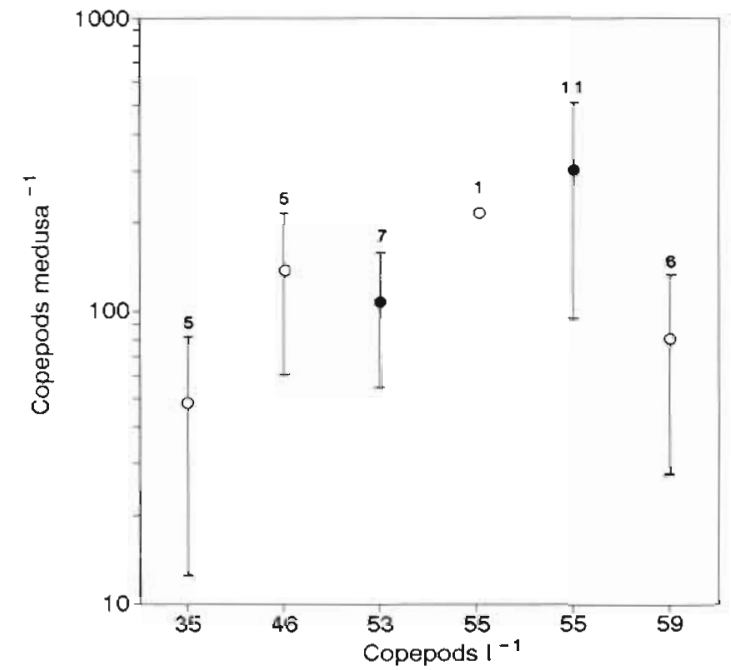

Fig. 4. Chrysaora quinquecirrha. Comparison of feeding by medusae during $(0)$ the day and $(\bullet)$ night at different copepod densities at Stn 4 in Chesapeake Bay on August 20,1987 and August 16, 1990. Data points indicate the mean no. ( \pm 1 SD) of copepods medusa ${ }^{-1}$ The no. of medusae examined appears above each bar

tion rates from field data on prey density, medusa size distribution, and temperature.

Predation effects (percentage of the copepod standing stock consumed $\mathrm{d}^{-1}$ ) of Chrysaora quinquecirrha medusae were calculated from medusa gut contents and digestion rates, plus densities of medusae and copepods in 2 tributaries of Chesapeake Bay in 1987 and 1988, and at bay Stn 5 in 1987 (Table 5). The average no. of copepods in each medusa ranged from 14 to 92. Digestion times, calculated from water temperature and the no. of prey in the medusae, ranged from 2 to $3 \mathrm{~h}$ (Table 5). In the tributaries in 1987, medusa densities increased from $1 \mathrm{~m}^{-3}$ in early June to $11-13 \mathrm{~m}^{-3}$ in August, but in 1988 their densities were highest on June 21. The most copepods $\mathrm{m}^{-3} \mathrm{~d}^{-1}$ were eaten in the Tred Avon River on August 18, 1987 (10700) and on June 21, 1988 (7366) when medusa densities were greatest. Copepod densities in the tributaries seemed to decrease over the season, and were very low in late August ( 400 to $2300 \mathrm{~m}^{-3}$ ). In 1987, predation effects in Tred Avon River and Broad Creek were lowest in early June ( 2 and $7 \% \mathrm{~d}^{-1}$ ) when medusae were in low densities, but in 1988 , the highest predation was on June 21 (42 and $\left.86 \% \mathrm{~d}^{-1}\right)$. The greatest predation was observed in the Tred Avon River in both years (86 and $94 \% d^{-1}$ ) In both years, predation was generally 20 to $50 \% \mathrm{~d}^{-1}$ of the copepod standing stock.

In contrast to the tributaries, at bay $\operatorname{Stn} 5$, medusa densities were lower $\left(0.2\right.$ to $\left.2.1 \mathrm{~m}^{-3}\right)$. Also, copepod densities were generally much higher (11622 to $22539 \mathrm{~m}^{-3}$ ) and increased in June through August.
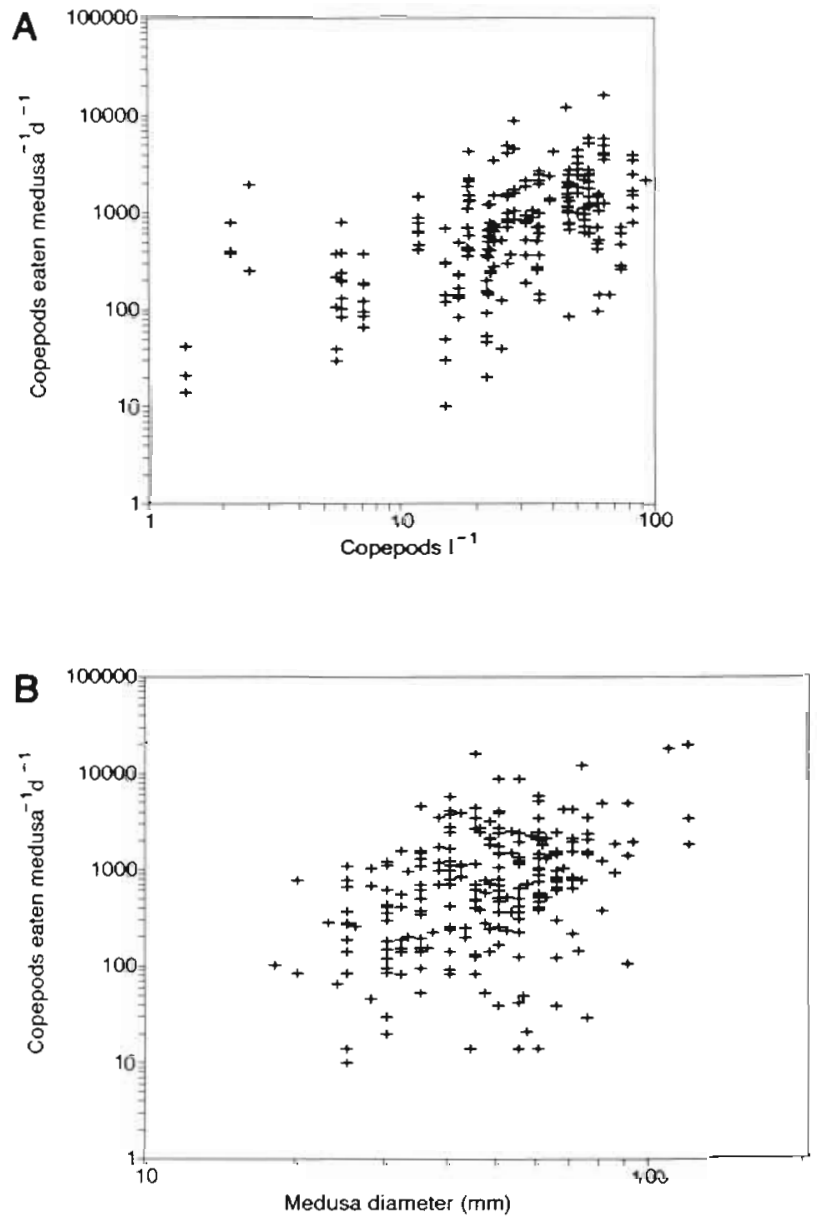

Fig. 5. Chrysaora quinquecirrha. Feeding rates (copepods eaten medusa ${ }^{-1} \mathrm{~d}^{-1}$ ) vs (A) copepod density and (B) medusa diameter for 240 medusae collected at 5 stations in Chesapeake Bay in 1987 to 1990 . Feeding rate was also significantly related to water temperature (Table 4 )

Table 4. Chrysaora quinquecirrha. Multiple regression analysis of copepod density, preserved medusa diameter, and temperature on feeding rates on copepods by 240 medusae in situ. Regression equation: $\log Y=0.85 \log X_{1}+1.43 \log X_{2}+$ $3.96 \log X_{3}-6.43 ;$ ANOVA $F=75.2, \mathrm{p}=1.0 \times 10^{-14^{\circ}} ; \mathrm{SE}$ of estimate $=0.44$

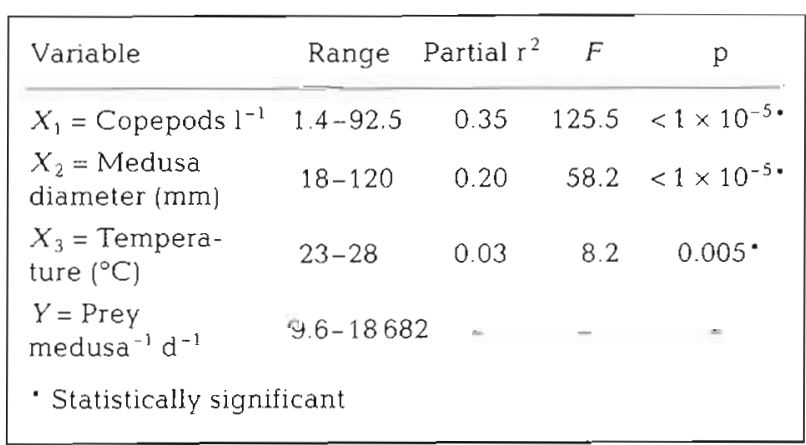


Table 5. Chrysaora quinquecirrha. Water temperature, no. of medusae examined for gut contents determination, no. of copepods eaten, digestion time, density of medusae $>6 \mathrm{~mm}$ and copepods, and predation effects of medusae on copepods. Medusa diameters are from gut content samples (mean \pm SD) and from net samples (averages in parentheses). Data are presented for 2 tributaries in 1987 and 1988, and at Stn 5 in Chesapeake Bay in 1987. ND: no data due to equipment failure

\begin{tabular}{|c|c|c|c|c|c|c|c|c|c|}
\hline $\begin{array}{l}\text { Location } \\
\text { Date }\end{array}$ & $\begin{array}{l}\text { Temper- } \\
\text { ature }\left({ }^{\circ} \mathrm{C}\right)\end{array}$ & $\begin{array}{l}\text { No. medusae } \\
\text { examined }\end{array}$ & $\begin{array}{l}\text { Diameter } \\
\text { (mm) }\end{array}$ & $\begin{array}{l}\text { No copepods } \\
\text { medusa }^{-1}\end{array}$ & $\begin{array}{c}\text { Digestion } \\
\text { time }(\mathrm{h})\end{array}$ & $\begin{array}{c}\text { Medusae } \\
\mathrm{m}^{-3}\end{array}$ & $\begin{array}{l}\text { No. copepods } \\
\text { eaten } \mathrm{m}^{-3} \mathrm{~d}^{-1}\end{array}$ & $\begin{array}{l}\text { No. copepods } \\
\mathrm{m}^{-3}\end{array}$ & $\begin{array}{c}\% \text { eaten } \\
d^{-1}\end{array}$ \\
\hline \multicolumn{10}{|c|}{ Broad Creek, 1987} \\
\hline Jun 8 & 25.0 & 4 & $40 \pm 24(16)$ & 38.2 & 3.1 & 1.1 & 325.3 & 4200 & 7.2 \\
\hline July 8 & 28.0 & 8 & $47 \pm 18(14)$ & 55.6 & 2.2 & 7.0 & 4245.8 & 29100 & 12.7 \\
\hline Aug 4 & 28.3 & 11 & $40 \pm 12(28)$ & 19.4 & 2.1 & 7.1 & 1574.2 & 1770 & 47.1 \\
\hline Aug 11 & 28.9 & 10 & $31 \pm 6(21)$ & 21.7 & 1.9 & 11.0 & 3015.2 & 2670 & 53.0 \\
\hline Aug 18 & 27.8 & 8 & $38 \pm 14(24)$ & 21.9 & 2.3 & 3.0 & 685.6 & 2300 & 23.0 \\
\hline \multicolumn{10}{|c|}{ Broad Creek, 1988} \\
\hline Jun 21 & 28.5 & 7 & $33 \pm 28(15)$ & 33.6 & 2.1 & 2.0 & 768.0 & 2330 & 24.8 \\
\hline Jul 19 & 28.3 & 10 & $47 \pm 20(24)$ & 56.0 & 2.2 & 2.7 & 1649.4 & ND & - \\
\hline Aug 23 & 26.0 & 17 & $31 \pm 8(26)$ & 28.9 & 2.9 & 2.6 & 621.9 & ND & - \\
\hline \multicolumn{10}{|c|}{ Tred Avon, 1987} \\
\hline Jun 8 & 26.0 & 4 & $68 \pm 35(11)$ & 92.2 & 2.9 & 0.4 & 305.2 & 15080 & 2.0 \\
\hline Jul 8 & 28.0 & 18 & $36 \pm 14(26)$ & 49.7 & 2.2 & 7.4 & 4012.1 & 6510 & 38.1 \\
\hline Aug 11 & 29.1 & 19 & $32 \pm 18(23)$ & 76.5 & 1.9 & 6.6 & 6377.8 & 18200 & 26.0 \\
\hline Aug 18 & 28.2 & 8 & $37 \pm 12(23)$ & 732 & 2.2 & 13.4 & 10700.5 & 690 & 93.9 \\
\hline \multicolumn{10}{|c|}{ Tred Avon, 1988} \\
\hline Jun 21 & 28.5 & 10 & $33 \pm 16(13)$ & 39.3 & 2.1 & 9.7 & 4356.7 & 1230 & 78.0 \\
\hline Jul 19 & 28.3 & 7 & $38 \pm 20(18)$ & 14.0 & 2.1 & 7.4 & 1184.0 & ND & - \\
\hline Aug 23 & 26.0 & 9 & $27 \pm 11(23)$ & 28.0 & 2.9 & 1.4 & 324.4 & 400 & 44.8 \\
\hline \multicolumn{10}{|c|}{ Bay Station 5, 1987} \\
\hline Jul 9 & 27.2 & 8 & $55 \pm 13(28)$ & 71.4 & 2.6 & 0.2 & 131.8 & 11622 & 1.1 \\
\hline Aug 6 & 27.9 & 11 & $45 \pm 7(34)$ & 13.9 & 2.2 & 2.4 & 363.9 & 16788 & 2.1 \\
\hline Aug 13 & 27.1 & 8 & $34 \pm 8(27)$ & 58.4 & 2.8 & 1.1 & 550.6 & 22539 & 2.4 \\
\hline Aug 20 & 27.3 & 8 & $42 \pm 13(29)$ & 50.1 & 2.5 & 1.3 & 625.2 & 22027 & 2.8 \\
\hline
\end{tabular}

Predation effects were much lower at Stn 5 than in the tributaries; only 1 to $3 \% \mathrm{~d}^{-1}$ of the copepods were consumed by medusae at Stn 5 .

The daily rations, excretion rates, and body weights in terms of nitrogen were calculated from gut content data, water temperatures, and mean medusa diameters given in Table 5 (Fig. 6). The daily nitrogen ration ranged from 42.6 to $252.0 \% \mathrm{~d}^{-1}$ of ammonium excretion. The rations of medusae $<45 \mathrm{~mm}$ in diameter exceeded their excretion $\left(145.0 \pm 65.3 \% \mathrm{~d}^{-1}\right)$ in all but
Fig. 6. Chrysaora quinquecirrha. Partial nitrogen budget for medusae. (a) Biomass $(\mu \mathrm{g} N$ medusa ${ }^{-1}$ ), $(\times)$ excretion ( $\mu \mathrm{g} \mathrm{NH}_{4}{ }^{+}-\mathrm{N}$ medusa ${ }^{-1}$ $\mathrm{d}^{-1}$ ), and (血, 春, $\square$ ) ration from zooplankton $(\mu \mathrm{g} \mathrm{N}$ medusa ${ }^{-1} \mathrm{~d}^{-1}$ ) calculated for medusae sampled in June, July and August 1987 respectively (see Table 5). Rectangles labelled with B7, B8, T7, and T $8=$ Broad Creek and Tred Avon River in 1987 and 1988 respectively, and those without labels are from Stn 5 in Chesapeake Bay in 1987. Preserved medusa diameters were converted to live diam ters using the conversion in Table 1

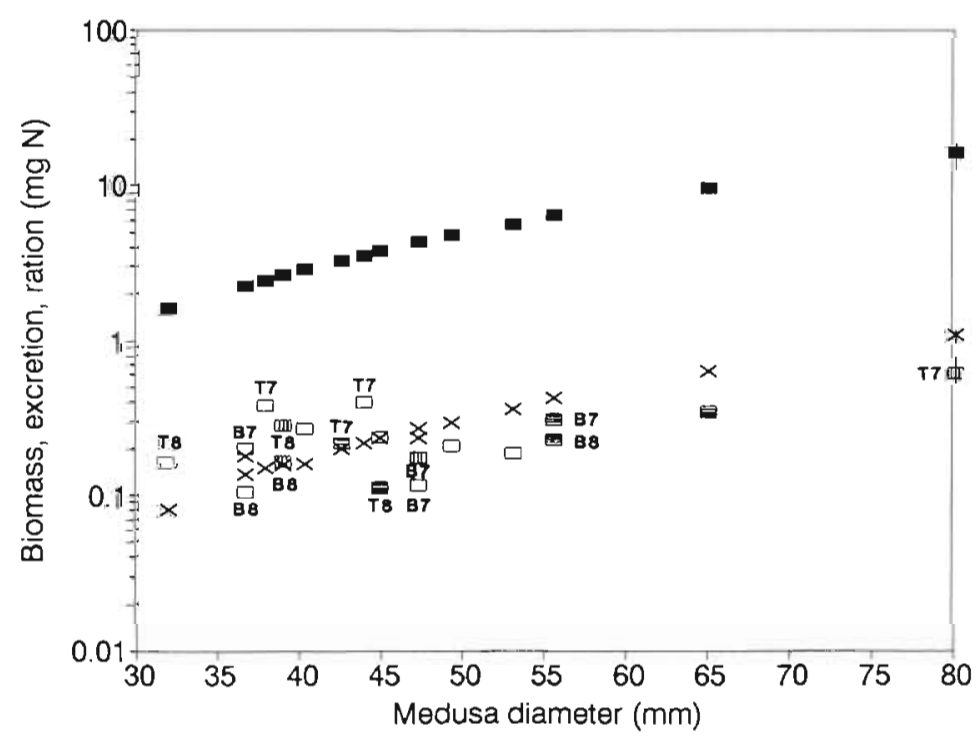


2 samples, but the rations of medusae $>45 \mathrm{~mm}$ supplied only $65.3 \pm 19.4 \% \mathrm{~d}^{-1}$ of excretion, exceeding excretion in only 1 sample. Because other forms of nitrogen are also excreted in lesser amounts, these percentages are somewhat high. From 2.7 to $15.4 \%$ of the body nitrogen was assimilated from zooplankton daily. Medusae $<45 \mathrm{~mm}$ in diameter obtained $8.6 \pm$ $3.6 \% \mathrm{~d}^{-1}$ of their body nitrogen from prey, whereas medusae $>45 \mathrm{~mm}$ obtained only $4.0 \pm 1.1 \% \mathrm{~d}^{-1}$.

\section{DISCUSSION}

Much higher densities and biomasses of Chrysaora quinquecirrha medusae occurred in the tributaries sampled in this study (maximum 18.6 medusae $\mathrm{m}^{-3}$ and $69 \mathrm{ml} \mathrm{m}^{-3}$ respectively) than at the nearshore bay Stn 5 (maximum 2.4 medusae $\mathrm{m}^{-3}$ and $22 \mathrm{ml} \mathrm{m}^{-3}$ respectively). Even fewer medusae were found in the mid-bay stations than at Stn 5 during July and August 1987, when mean densities for 5 stations along the transect in Chesapeake Bay were 0.1 and 0.6 medusae $\mathrm{m}^{-3}$ respectively (Purcell et al. 1991). The volumes $\mathrm{m}^{-3}$ of medusae sampled in Broad Creek and the Tred Avon River generally were similar to those reported for other tributaries of Chesapeake Bay; however, greater biomass was recorded 4 times at 1 upstream station in the Lafayette River, Virginia, USA, $\left(80\right.$ to $120 \mathrm{ml} \mathrm{m}^{-3}$; Kelly 1983, Feigenbaum \& Kelly 1984). The volumes $\mathrm{m}^{-3}$ measured at downstream stations in the Lafayette River were much less than those in Broad Creek and the Tred Avon River. In the Patuxent River, Maryland, USA, in 1964, the peak biomass of ctenophores and medusae combined was $39 \mathrm{ml} \mathrm{m}^{-3}$ (Miller \& Williams 1972). In the Pamlico River, North Carolina, USA, in 1967-1968, the maximum biomass measured for $C$. quinquecirrha medusae was only $5 \mathrm{ml} \mathrm{m} \mathrm{m}^{-3}$ (Miller 1974).

Food items found in gut contents have been listed for many species of scyphomedusae (reviewed in Larson 1978 and Alvarino 1985, additional data in Kelly 1983, Larson 1987b, Fancett 1988, Brewer 1989, Giorgi et al 1991, Larson 1991, Zavodnik 1991). All species exam- ined so far consume a variety of zooplankton prey. often eating many other gelatinous zooplankton (Purcell 1991). Both gut contents and available prey were quantified in a few of the following studies so that prey selection could be determined. Cyanea capillata and Pseudorhiza haeckeli showed positive selection for fish eggs and yolk-sac larvae, and negative selection for other prey taxa, including copepods (Fancett 1988). Giorgi et al. (1991) concluded that Pelagia noctiluca was not a selective feeder, but selection analyses were not performed. Chrysara quinquecirrha in the present study showed positive selection only for copepods. Bivalve veligers were selected against, and these medusae did not digest bivalve veligers even when ingested (Purcell et al. 1991). In contrast, Stomolophus meleagris selected bivalve veligers over all other prey taxa in the Gulf of Mexico (Larson 1991).

In contrast to the diet of the medusae $\geq 18 \mathrm{~mm}$ diameter that I studied, the diet of ephyrae and medusae $<6 \mathrm{~mm}$ in live diameter predominantly consisted of protozoans and rotifers (Table 6; data from Haven \& Morales-Almo 1973). Selection by these small medusae was negative for copepod nauplii, polychaete larvae, and gastropod veligers, but was positive for rotifers (Table 6).

Acartia tonsa is the predominant copepod species in the mesohaline region of Chesapeake Bay during the summer (Olson 1987). I considered predation effects by medusae only on copepods (copepodites and adults) because they were the most numerous prey item, they could be identified at all stages of digestion, they were selected for by the medusae, and they were produced within the plankton. No ather prey taxa met these criteria.

Prey taxa other than zooplankton are important components of the diet of Chrysaora quinquecirrha, especially for large medusae, because zooplankton alone did not meet the nitrogen demands of medusae $>45 \mathrm{~mm}$ in diameter. Ctenophores, which are eaten by the medusae, were not included in the gut content analyses because they are digested very rapidly, and could not be quantified (Purcell unpubl.). Mnemiopsis leidyi ctenophores were absent from Broad Creek and

Table 6. Zooplankton in the diet of ephyrae and Chrysaora quinquecirha medusae < $6 \mathrm{~mm}$ in diameter ( $\mathrm{n}=212$ ), and in the water (collected with a $75 \mu \mathrm{m}$ mesh net). Mean data from 14 samples from Sarah Creek, Virginia during May 24 to July 17,1972 (data from Haven \& Morales-Almo 1973). Prey selection indices (C) calculated according to Pearre (1982). ND: no data

\begin{tabular}{|c|c|c|c|c|c|c|}
\hline & Protozoa & Rotifers & $\begin{array}{c}\text { Copepod } \\
\text { nauplii }\end{array}$ & $\begin{array}{c}\text { Polychaete } \\
\text { larvae }\end{array}$ & $\begin{array}{c}\text { Gastropod } \\
\text { veligers }\end{array}$ & Other \\
\hline No. prey in diet & 923 & 353 & 11 & 8 & 1 & 214 \\
\hline No. prey l-1 & ND & 0.54 & 5.06 & 1.21 & 1.28 & ND \\
\hline C & - & $0.569^{\circ}$ & $-0.192^{\circ}$ & $-0.060^{\circ}$ & $-0.074^{\prime}$ & - \\
\hline
\end{tabular}


the Tred Avon tributaries during June through August, 1987, but they were abundant in the bay (Purcell et al. 1991). At Stn 5, the density of ctenophores on June 9 was $3.4 \mathrm{~m}^{-3}$ and their average size was $270 \mu \mathrm{g} \mathrm{N}$; in August, the mean density was $0.2 \pm 0.2$ ctenophores $\mathrm{m}^{-3}$, and the average size was $5293 \mu \mathrm{g} N$ (Nemazie 1991, Purcell unpubl.). Therefore, ctenophores are potentially important in the diet of $C$. quinquecirrha medusae. Medusae in the tributaries often contained large benthic polychaetes and fish larvae (Fundulus spp.) (Purcell unpubl). Bay anchovy eggs were abundant in the gut contents of medusae in July, and the magnitude of medusa predation on the eggs is currently being studied (Houde \& Purcell unpubl.). These prey taxa also would provide an important dietary supplement.

In situ daily rations from zooplankton (excluding ctenophores and ichthyoplankton) exceeded the metabolic demands of small Chrysaora quinquecirrha medusae (mean $145 \%$ ), but not of large medusae (mean 65\%). Larson (1991) found that ingestion by another scyphomedusan, Stomolophus meleagris, was about 100 to $300 \%$ of the maintenance ration. Similarly, the rations of large specimens of other gelatinous taxa have been found to be less than or approximately equal to maintanence needs, whereas rations of small specimens greatly exceeded maintenance (>1000\%) (Larson 1987b, Siferd \& Conover 1992). In situ daily rations of gelatinous zooplankton often are high percentages of the predator body weight - for ctenophores 10 to $>100 \%$ (Larson 1987b, Siferd \&
Conover 1992), for hydromedusae 3 to $>100 \%$ (Larson $1987 \mathrm{~b}$ ) and 244 to $>2000 \%$ (Matsakis \& Conover 1991). For scyphomedusae, I found the zooplankton nitrogen ration of C. quinquecirrha to be only 3 to $15 \%$ of the medusa nitrogen weight. Matsakis \& Conover (1991) estimated the carbon ration for Aurelia aurita to be $400 \%$ of the medusa carbon weight. Rations measured in the laboratory have been 5 to $40 \%$ of scyphomedusa weight (Morand et al. 1987, Bamstedt 1990).

Feeding rates of Chrysaora quinquecirrha medusae have been reported twice before (Table 7). The diet, digestion times, and feeding rates reported here for C. quinquecirrha in the mesohaline region of Chesapeake Bay are similar to those reported in a field study in the southern Bay (Kelly 1983). However, only very small medusae ( 1 to $39 \mathrm{ml}$ volume) were present in the Lafayette River (Kelly 1983), while specimens in the present study ranged up to $165 \mathrm{ml}$ in volume. Kelly's (1983) equation relating size-specific feeding rates (prey consumed $\mathrm{d}^{-1} \mathrm{ml}$ medusa ${ }^{-1}$ ) to medusa volume cannot be used for medusae larger than $33 \mathrm{ml}$, because larger medusa volumes yield negative feeding rates (Table 7). In contrast, Kelly's (1983) equation relating feeding rate $\mathrm{d}^{-1}$ medusa $^{-1}$ from medusa volume gives rates within the range calculated in the present study (Table 7). The lack of prey density data in Kelly (1983) makes it difficult to compare medusa feeding rates from these 2 studies, because prey density had the greatest effect on feeding rate (Table 4).

Table 7. Chrysaora quinquecirrha. Comparison of feeding rates measured in different studies. Predicted feeding rates were calculated from the equations presented in each study, but using field data on copepod density, medusa volume or diameter, and temperature from the present study. ND: no data

\begin{tabular}{|c|c|c|c|}
\hline Protocol & Clifford \& Cargo (1978) & Kelly (1983) & Present \\
\hline Condition & 5 l bucket & Field & Field \\
\hline Prey type & Artemia nauplii & Copepods & Copepods \\
\hline Prey $1^{-1}$ & $600-10600$ & ND & $1.4-92.5$ \\
\hline \multicolumn{4}{|l|}{ Medusa size (live) } \\
\hline Volume (ml) & $50-262$ & $1-39$ & $1.5-165.3^{a}$ \\
\hline Diameter (mm) & ND & $N D$ & $21-142$ \\
\hline \multicolumn{4}{|l|}{ Measured feeding rates } \\
\hline Prey d $\mathrm{d}^{-1} \mathrm{ml} \mathrm{medusa}^{-1}$ & $72-2568$ & $1.0-35.7$ & $0.4-1041.6$ \\
\hline Prey $\mathrm{d}^{-1}$ medusa $^{-1}$ & ND & $17.8-508.4$ & $9.6-18682$ \\
\hline \multicolumn{4}{|l|}{ Predicted feeding rates } \\
\hline Prey $\mathrm{d}^{-1} \mathrm{ml}_{\text {medusa }}{ }^{-1}$ & $0.26-17.26^{\mathrm{b}}$ & 28.9 to $-118.5^{c}$ & $5.2-52.7^{d}$ \\
\hline Prey $\mathrm{d}^{-1}$ medusa $^{-1}$ & ND & $90.8-1191.1^{d}$ & $7.7-8709.6^{\mathrm{e}}$ \\
\hline \multicolumn{4}{|c|}{ 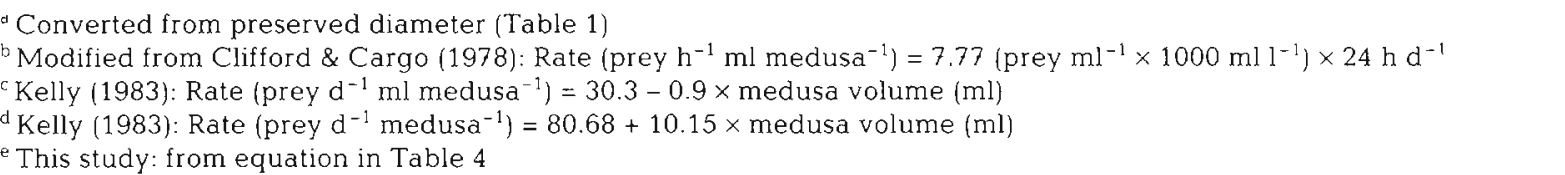 } \\
\hline
\end{tabular}


Clifford \& Cargo (1978) measured feeding on Artemia salina nauplii by Chrysaora quinquecirrha medusae in small containers. Size-specific feeding rates (prey consumed $\mathrm{d}^{-1} \mathrm{ml}^{-1}$ ) calculated from their equation, but using copepod densities from the present study, are very low in comparison with rates predicted from the field studies (Table 7). Reduced feeding by gelatinous zooplankton in small containers has been illustrated several times (e.g. de Lafontaine \& Leggett 1987, Purcell \& Nemazie 1992). The medusae may have been disturbed in confined conditions, or their feeding saturated at the high prey densities offered, or A. salina nauplii captured less well than copepods. The results of the present study illustrate that both prey density and medusa size are critical to predict feeding rates of $C$. quinquecirrha.

Clearance rates of some scyphomedusae have been measured in a few studies (Table 8). Because the conditions and prey have differed, it is not possible to compare rates among species. For medusae of similar sizes, clearance rates increased with prey size, from microzooplankton to copepods to fish eggs and larvae. Clearance rates of one prey type should not be used to predict clearance rates of other prey types, as often is done, because the various types of prey are captured with different success, as illustrated by the 75 -fold difference between clearance rates of copepods and of fish eggs by Stomolophus meleagris. Container size also affected clearance rate, which generally was higher in large containers and in the field. Clearance rates of fish larvae by Aurelia aurita increased with increasing size of large in situ enclosures (de Lafontaine \& Leggett 1987). However, clearance rates of Chrysaora quinquecirrha medusae feeding on Artemia salina nauplii in $20 \mathrm{l}$ containers were very high (240 l cleared $\mathrm{d}^{-1}$ ) compared with clearance rates on copepods estimated from field data $\left(15.7 \mathrm{l} \mathrm{d}^{-1}\right)$ in the present study (Table 8). In situ clearance rates of copepods by $C$. quinquecirrha were most similar to rates measured in situ on copepod prey of $S$. meleagris (Table 8).

The feeding rates and predation effects calculated here for Chrysaora quinquecirrha are my best estimates, however there are some potential sources of error. The mean sizes of medusae collected for gut content analyses were larger than the average sizes of the general population (Table 5). This may have lead to overestimates, because medusa size significantly affected feeding rate (Table 4). However, predation effects also were underestimated because onlymedusae $>6 \mathrm{~mm}$ in diameter were included in the densities (Table 5). Ephyrae and young medusae occurred in high densities in the tributaries, especially in late June. On June 23, 1987, their densities were $1.1 \mathrm{~m}^{-3}\left(24.7 \%\right.$ of the population) and $7.6 \mathrm{~m}^{-3}(41.6 \%)$ in Broad Creek and the Tred Avon River, respectively, and similarly on June 21, 1988, their densities were $4.6 \mathrm{~m}^{-3}(69.5 \%)$ and $15.3 \mathrm{~m}^{-3}(61.2 \%)$. The feeding rates of these small medusae are not known. Even

Table 8. Clearance rates of prey by scyphomedusae. Medusa diameters are given in parentheses. Volumes $\left(1\right.$ or $\left.\mathrm{m}^{3}\right)$ of containers are given under 'Condition'

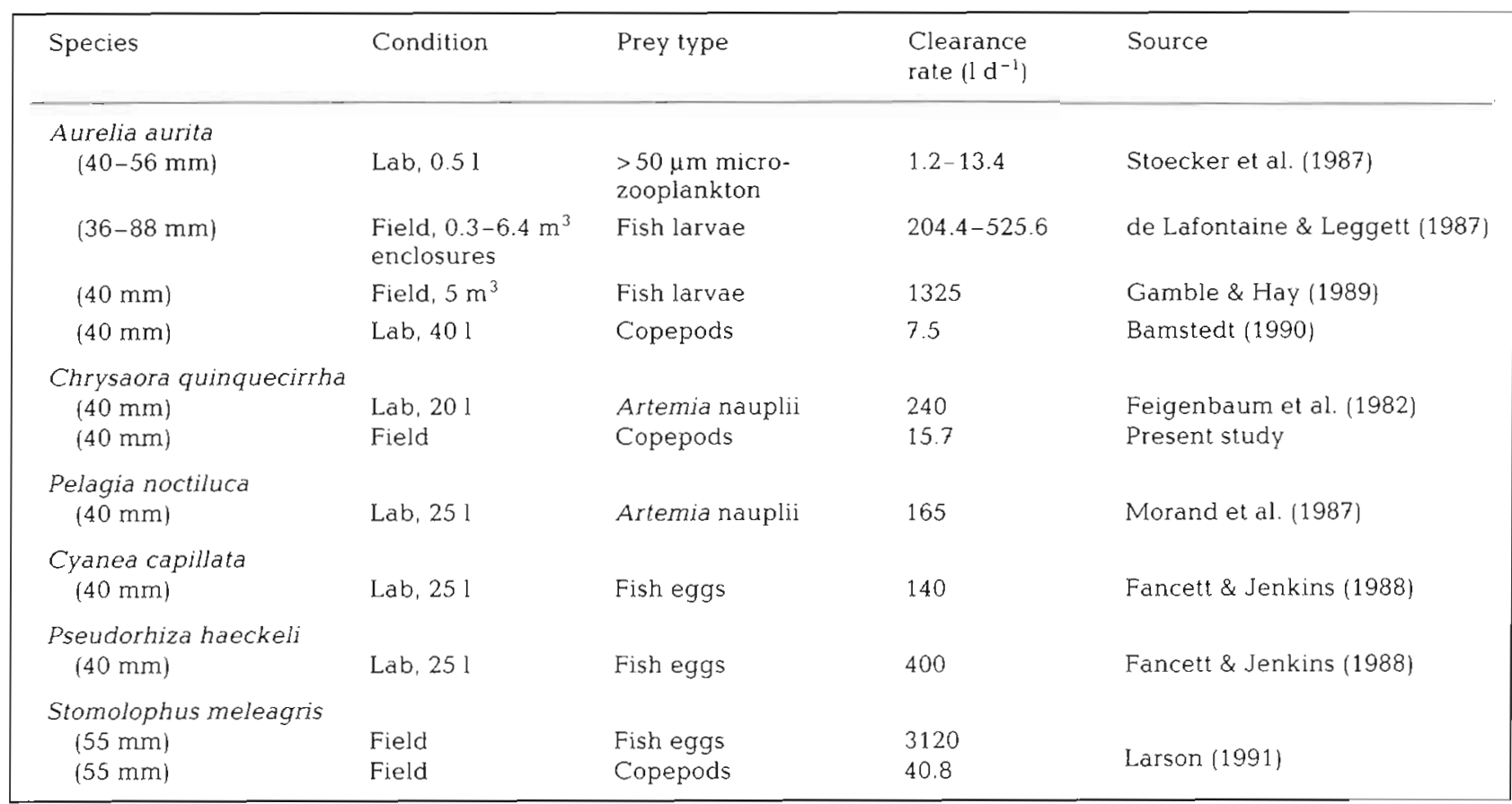


greater densities of $C$. quinquecirrha were measured in the tributaries on dates other than those when predation effects were calculated (Figs. 1 \& 2, Table 5), and predation effects on those dates could have been greater than those calculated here. Feeding was assumed to be constant over $24 \mathrm{~h}$, however, copepod densities at the deep mid-bay $\operatorname{Stn} 4$ increased in the surface waters at night, thereby increasing medusa feeding (Fig. 4). Medusa densities also were greater at night at Stn 4 (Nemazie 1991). However, due to the shallow depths of the stations reported here $(\leq 5 \mathrm{~m})$, constant feeding and medusa densities during day and night probably are reasonable assumptions.

The predation effects of Chrysaora quinquecirrha medusae on prey populations in the tributaries (maximum $94 \%$ eaten $\mathrm{d}^{-1}$ ) are greater than any reported for other scyphomedusae. Aurelia aurita consumed 2.6 and $4.4 \%$ herring larvae $\mathrm{d}^{-1}$ during 2 years in Kiel Bight, Germany (Moller 1980). Fancett \& Jenkins (1988) calculated that Cyanea capillata and Pseudorhiza haeckeli removed up to 2.4 and $3.8 \% \mathrm{~d}^{-1}$, respectively, of fish eggs and yolksac larvae in Port Phillip Bay, Australia. Those species removed 1.6 and $4.8 \% \mathrm{~d}^{-1}$, respectively, of the copepod populations, representing $<5 \%$ of the total daily mortality rates of the copepods (Fancett \& Jenkins 1988). These rates are similar to those calculated for $C$. quinquecirrha at bay Stn 5 .

Production rates of Acartia tonsa copepods ranged from 105 to $125 \% \mathrm{~d}^{-1}$ at temperatures of 25 to $29^{\circ} \mathrm{C}$ between June and August in mid-Chesapeake Bay (White 1991), thus Chrysara quinquecirrha medusae removed $<2.5 \% \mathrm{~d}^{-1}$ of the copepod production in the bay. However, if those production rates occurred in the tributaries, then medusae consumed 2 to $7 \% \mathrm{~d}^{-1}$ of the copepod production in June, and 10 to $78 \% \mathrm{~d}^{-1}$ of the production in July and August. This could detrimentally affect copepod populations in the tributaries.

Acknowledgements. This research was funded by NOAA grants NA86AA-D-SG006 and NA90AA-D-SG063 to the University of Maryland Sea Grant College. R. I. E. Newell, G. S. Alspach, and T. C. Malone graciously allowed me to sample on their research cruises in 1987. I thank F. P. Cresswell and D. C. Kennedy for the many tedious hours spent in the laboratory, and F. P. Cresswell and D. A. Nemazie for their assistance in the field. M. R. Roman permitted the use of zooplankton data from Chesapeake Bay. V. S. Kennedy, P. Kremer, and C. A. Miller provided comments on the manuscript. UMCEES Contribution No. 2336.

\section{LITERATURE CITED}

Alvarino, A. (1985). Predation in the plankton realm; mainly with reference to fish larvae. Invest. mar. cent. interdisc. Ciencias mar. 2: 1-22

Baird, D., Ulanowicz, R. E. (1989). The seasonal dynamics of the Chesapeake Bay ecosystem. Ecol. Monogr. 59: 329-364
Bamstedt, U. (1990). Trophodynamics of the scyphomedusae Aurelia aurita. Predation rate in relation to abundance, size and type of prey organism. J. Plankton Res. 12: $215-229$

Brewer, R. H. (1989). The annual pattern of feeding, growth, and sexual reproduction in Cyanea (Cnidaria, Scyphozoa) in the Niantic river estuary, Connecticut. Biol. Bull. 176: $272-281$

Cargo, D. G., King, D. R. (1990). Forecasting the abundance of the sea nettle, Chrysaora quinquecirrha, in the Chesapeake Bay. Estuaries 13: 486-491

Cargo, D. G., Schultz, L. P. (1966). Notes on the biology of the sea nettle, Chrysaora quinquecirrha, in Chesapeake Bay. Chesapeake Sci. 7: 95-100

Cargo, D. G., Schultz, L. P. (1967). Further observations on the biology of the sea nettle and jellyfishes in the Chesapeake Bay. Chesapeake Sci. 8: 209-220

Clifford, H. C., Cargo, D. G. (1978). Feeding rates of the sea nettle, Chrysaora quinquecirrha, under laboratory conditions. Estuaries 1: 58-61

de Lafontaine, Y, Leggett, C. (1987). Effect of container size on estimates of mortality and predation rates in experiments with macrozooplankton and larval fish. Can J. Fish. Aquat. Sci. 44: 1534-1543

Fancett, M. S. (1988). Diet and prey selectivity of scyphomedusae from Port Phillip Bay, Australia. Mar Biol. 98: $503-509$

Fancett, M. S., Jenkins, G. P. (1988). Predatory impact of scyphomedusae on ichthyoplankton and other zooplankton in Port Phillip Bay. J. exp. mar. Biol Ecol. 116: 63-77

Feigenbaum, D., Kelly, M. (1984). Changes in the lower Chesapeake Bay food chain in presence of the sea nettle Chrysaora quinquecirrha (Scyphomedusa). Mar. Ecol. Prog. Ser. 19: 39-47

Feigenbaum, D. L., Knowles, D., Kelly, M. (1982). Trophic interactions of the sea nettle, Chrysaora quinquecirrha. Technical Rept. No. 82-2, Dept. of Oceanography, Old Dominion Univ., Virginia

Gamble, J. C., Hay, S. J. (1989). Predation by the scyphomedusan Aurelia aurita on herring larvae in large enclosures: effects of predator size and prey starvation. Rapp P.-v. Réun. Cons. int. Explor. Mer 191: 366-375

Giorgi, R., Avian, M., De Olazabal, S., Rottini Sandrini, L. (1991). Feeding of Pelagia noctiluca in open sea. In Jellyfish blooms in the Mediterranean. Proc. 2nd Workshop on Jellyfish in the Mediterranean Sea. United Nations Environment Programme, Mediterranean Action Plan Tech. Repts. Ser. No. 47: 102-111

Haven, D. S., Morales-Almo, R. (1973). Contents of the gastrovascular cavity of ephyrae and young medusae of the sea nettle Chrysaora quinquecirrha in a tributary of the York River, Virginia. In: Zubkoff, P. (ed.) Control measures for Chesapeake Bay jellyfish. Annual Report for NMFS Contract N- 043-226-72 (G), Virginia Institute of Marine Science, p. 22-52

Kelly, M. G. (1983). The effect of sea nettle abundance on the food chain of the lower Chesapeake Bay. M.S. thesis, Old Dominion Univ., Virginia

Larson, R. J. (1978). Aspects of feeding and functional morphology of scyphomedusae. M.S. thesis, Univ. of Puerto Rico

Larson, R. J. (1987a). Daily ration and predation by medusae and ctenophores in Saanich Inlet, B.C., Canada. Netherlands J. Sea Res. 21: 35-44

Larson, R. J. (1987b). A note on the feeding, growth, and reproduction of the epipelagic scyphomedusa Pelagia noctiluca (Forskal). Biol. Oceanogr. 4: 447-454 
Larson, R. J. (1991). Diet, prey selection, and daily ration of Stomolophus meleagris, a filter-feeding scyphomedusa from the NE Gulf of Mexico. Estuar. coast. Shelf Sci. 32: 511-525

Malone, T. C., Kemp, W. M., Ducklow, H. W., Boynton, W. R., Tuttle, J. H., Jonas, R. B. (1986). Lateral variation in the production and fate of phytoplankton in a partially stratified estuary. Mar. Ecol. Prog. Ser. 32: 149-160

Matsakis, S., Conover, R. J. (1991). Abundance and feeding of medusae and their potential impact as predators on other zooplankton in Bedford Basin (Nova Scotia, Canada) during spring. Can J. Fish. Aquat. Sci. 48: $1419-1430$

Miller, R. J. (1974). Distribution and biomass of an estuarine ctenophore population, Mnemiopsis leidyi. Chesapeake Sci. 15: 1-8

Miller, R. J., Williams, R. B. (1972). Energy requirements and food supplies of ctenophores and jellyfish in the Patuxent River Estuary. Chesapeake Sci. 13: 328-331

Moller, H. (1980). Scyphomedusae as predators and food competitors of larval fish. Kieler Meeresforsch. 28: 90-100

Morand, P., Carré, C., Biggs, D. C. (1987). Feeding and metabolism of the jellyfish Pelagia noctiluca (Scyphomedusa. Semaeostomae). J. Plankton Res. 9: 651-655

Nemazie, D. A. (1991). Ammonium excretion by gelatinous zooplankton and its role in regeneration of nitrogen in Chesapeake Bay. M.S. thesis, Univ. of Maryland

OIson, M. M. (1987). Zooplankton. In: Heck, K. L. Jr (ed.) Ecological studies in the middle reach of Chesapeake Bay. Springer Verlag, Berlin, p. 38-81

Pearre, S. Jr (1982). Estimating prey preference by predators: uses of various indices, and a proposal of another based on $\chi^{2}$. Can. J. Fish. Aquat. Sci. 39: 914-923

This manuscript was presented by K. R. Tenore, Solomons, Maryland, USA
Purcell, J. E. (1983). Digestion rates and assimilation efficiencies of siphonophores fed zooplankton prey. Mar. Biol. 73: $257-261$

Purcell, J. E. (1991). A review of cnidarians and ctenophores feeding on competitors in the plankton. Hydrobiologia 216/217: 335-342

Purcell, J. E., Cresswell, F. P., Cargo, D. G., Kennedy, V. S. (1991). Differential ingestion and digestion of bivalve larvae by the scyphozoan Chrysaora quinquecirrha and the ctenophore Mnemiopsis leidyi. Biol. Bull. 180: $103-111$

Purcell, J. E., Nemazie, D. A. (1992). Quantitative feeding ecology of the hydromedusan Nemopsis bachei in Chesapeake Bay. Mar. Biol. 113: 305-311

Schultz, L. P., Cargo, D. G. (1971). The sea nettle of Chesapeake Bay. Education Series No. 93, Natural Resources Institute, Univ, of Maryland, College Park

Siferd, T. D., Conover, R. J. (1992). Natural history of ctenophores in the Resolute Passage Area of the Canadian High Arctic with special reference to Mertensia ovum. Mar. Ecol. Prog. Ser. 86: 133-144

Stoecker, D. K, Michaels, A. E., Davis, L. H. (1987). Grazing by the jellyfish, Aurelia aurita, on microzooplankton. J. Plankton Res. 9: 901-915

White, J. R. (1991). Seasonal study of zooplankton dynamics in the mesohaline Chesapeake Bay. Ph.D. dissertation, Univ, of Maryland, College Park

Zavodnik, D. (1987). On the food and feeding in the northern Adriatic of Pelagia noctiluca (Scyphozoa). In: Jellyfish blooms in the Mediterranean. Proc. 2nd Workshop on Jellyfish in the Mediterranean Sea. United Nations Environment Programme, Mediterranean Action Plan Tech. Repts. Ser. No. 47: 212-216

Manuscript first received: February 21, 1992

Revised version accepted: July 27, 1992 